\title{
Scale Parental Beliefs about Emotional Competence in Children (COMPE): Psychometric Properties
}

\author{
Deise Maria Leal Fernandes Mendes*, 1 \\ Orcid.org/0000-0003-3487-7284 \\ Pedro P. Pires ${ }^{2}$ \\ Orcid.org/0000-0001-8831-9056
}

Ana Carolina Monnerat Fioravanti ${ }^{3}$

Orcid.org/0000-0003-2340-4043

\author{
${ }^{1}$ Universidade do Estado do Rio de Janeiro, Rio de Janeiro, RJ, Brasil \\ ${ }^{2}$ Universidade Federal do Rio de Janeiro, Rio de Janeiro, RJ, Brasil \\ ${ }^{3}$ Universidade Federal Fluminense, Rio das Ostras, RJ, Brasil
}

\begin{abstract}
Parental beliefs regarding the emotional skills of children represent what parents think and believe about how the child develops in terms of emotion-related skills and which key abilities should be developed in this area. Emotional skill is a high impact component critical for full and healthy development. The aim of this study was to present, briefly, the construction steps of the COMPE scale and to verify the preliminary psychometric parameters, such as the dimensionality and reliability of the items. In order to reach the final form of the scale, Content Validity procedures were used for the constitution of the initial version and Item Response Theory (IRT) for the analysis of the psychometric properties of the items. As a result, the present article presents a scale with a total of 30 items capable of composing a measure for the parental beliefs mentioned, with three theoretical facets indicative of emotional skills linked to: (a) emotional expression, (b) emotional comprehension and (c) emotional regulation, which are aggregated into a single score. Based on the psychometric properties verified, it is considered that the COMPE can become an instrument option to be used with the Brazilian population in research involving parental beliefs and emotions.
\end{abstract}

Keywords: Emotional development, beliefs (nonreligious), scaling, COMPE.

\section{Escala Crenças Parentais sobre Competência Emocional em Crianças (COMPE): Propriedades Psicométricas}

\section{Resumo}

Crenças parentais sobre competências emocionais das crianças representam o que pais pensam e acreditam a respeito de como a criança se desenvolve em termos de habilidades ligadas a emoções

* Mailing address: Universidade do Estado do Rio de Janeiro, Rua São Francisco Xavier, 524, $10^{\circ}$ andar, Maracanã, Rio de Janeiro, RJ, Brazil 20550-900. E-mail: deisefmendes@gmail.com, ana@fioravantiana.org and ppires85@gmail.com

Financial support: Fundação de Amparo à Pesquisa do Estado do Rio de Janeiro (FAPERJ) and Conselho Nacional de Desenvolvimento Científico e Tecnológico (CNPq). 
e de quais capacidades principais nesse domínio deve desenvolver. A competência emocional é um componente crítico e impactante para o desenvolvimento pleno e saudável. O objetivo desse estudo foi o de apresentar, brevemente, as etapas de construção da escala COMPE e verificar os parâmetros psicométricos preliminares como dimensionalidade e confiabilidade dos itens. Para atingir a forma final da escala, foram adotados procedimentos de Validade de Conteúdo para a constituição da versão inicial e de Teoria de Resposta ao Item para a análise das propriedades psicométricas dos itens. Como resultado, o presente artigo apresenta uma escala com um total de 30 itens capazes de compor uma medida para as crenças parentais mencionadas, com três facetas teóricas indicativas de competências emocionais ligadas a: (a) expressão emocional, (b) compreensão emocional e (c) regulação emocional, que são agregadas sob um escore único. Com base nas propriedades psicométricas verificadas, considera-se que a COMPE passa a ser uma opção de instrumento a ser utilizado com população brasileira em pesquisas envolvendo crenças parentais e emoções.

Palavras-chave: Desenvolvimento emocional, crenças (não religiosas), escalas, COMPE.

\section{Escala Creencias de los Padres sobre la Competencia Emocional en los Niños (COMPE): Propiedades Psicométricas}

\section{Resumen}

Creencias parentales sobre las competencias emocionales de los niños representan lo que los padres piensan y creen acerca de cómo el niño se desarrolla en términos de habilidades vinculadas a emociones y de qué capacidades principales en ese dominio debe desarrollar. La competencia emocional es un componente crítico y impactante para el desarrollo pleno y saludable. El objetivo de este estudio fue presentar brevemente las etapas de construcción de escala COMPE y comprobar los parámetros psicométricos preliminares como dimensionalidad y confiabilidad de los ítems. Para conseguir la forma final de la escala, los procedimientos de Validez de Contenido se adoptaron para la creación de la versión inicial, y de Teoría de Respuesta para analizar las propiedades psicométricas de los ítems. Como resultado, este documento presenta una escala con un total de 30 ítems capaces de componer una medida de las creencias parentales mencionadas, con tres facetas teóricas indicativas de competencias emocionales relacionadas con: (a) expresión emocional, (b) comprensión emocional y (c) regulación emocional, que se agregan en una sola puntuación. Basado en las propiedades psicométricas verificadas, la COMPE se convierte en una opción de instrumento a ser utilizado con población brasileña, en investigaciones que implican emociones y creencias parentales.

Palabras clave: Desarrollo emocional, creencias (no religiosas), escala, COMPE.

Interconnections between parental beliefs and their parenting practices are evidenced and discussed in the literature (Harkness \& Super, 2010; Sheffield-Morris, Silk, Steinberg, Myers, \& Robinson, 2007). These beliefs can be transmitted directly to children through communication mechanisms such as narratives and instructions, affecting children's schemas about their personal identities and about the world at large (Bohanek et al., 2009; Fivush, 2008). Thus, parental beliefs regarding children's emotional skills seem to have an impact on their emotional development because they are guides to their behavior and/or reflect their behavioral inclinations, being transmitted to the children in order to instill in them understanding about how to deal with emotions (Parker et al., 2012).

In addition, parental beliefs about emotion, as well as being associated with the essential skills of children's emotional development, such as emotional regulation, emotional understanding, and emotional expression, are sensitive to the cultural context in which the child develops (Trommsdorff \& Cole, 2011). Investigating them 
constitutes a relevant way to increase knowledge about parenting and children's emotional development, expanding possibilities for action in seeking full and healthy development (Lozada, Halberstadt, Craig, Dennis, \& Dunsmore, 2016; Trommsdorff \& Cole, 2011). However, little is known about parental beliefs related to emotions, especially in Brazilian parents. As an aggravating factor, there are no instruments to evaluate the phenomenon in this population.

The relevance of emotion-related skills for a healthy, biologically and socially healthy life has been recognized and underlined by psychologists and neuroscientists in the last decades (Damásio, 2009; Denham, Ferrier, Howarth, Herndon, \& Bassett, 2016; Finlon et al., 2015; Goleman, 1995; Saarni, 1999). Some constructs related to this human skills domain have been proposed, with different emphases on the different aspects to be taken into account, with the notion of emotional intelligence formulated by Goleman (1995) being one that has caused great repercussions inside and outside Psychology.

Defined by this author as a set of skills that includes the control of impulses, self-motivation, empathy and social skill in interpersonal relationships, some initiatives have been carried out with the aim of instrumentalizing the measurement of emotional intelligence, such as the Veiga Scale of Emotional Competence (Mendonça, 2009) and the Emotional Competence Inventory (ECI; Boyatzis \& Sala, 2004). The development of these skills in ontogenesis and the parents' view regarding this, however, do not seem to be part of the concerns that guided this theoretical formulation and associated studies.

Starting from another theoretical perspective, Halberstadt et al. (2013) worked on the idea of parental beliefs about the emotions of the children. According to the authors, they constitute important aspects of the parental socialization of emotion and may be related to the mental health and well-being of the children. Thus, they developed a multifaceted questionnaire to evaluate the beliefs of parents regarding the emotions of their children, the Parents' Beliefs about Children's Emotions Questionnaire (PBACE), which consists of seven scales covering the reactions and ways of dealing with the emotional manifestations of children. However, perhaps the best-known empirical work on parental beliefs about emotions is parental meta-emotion (Gottman, Katz, \& Hooven, 1996). Although the meta-emotion measures developed demonstrate psychometric strong points, the construct itself combines the assessment of beliefs and behaviors, making it difficult to distinguish the impact of the parental beliefs from that which can be attributed to the parental behaviors.

The interest and theoretical concept assumed for the construction of the COMPE scale, proposed here, are different from the initiatives mentioned and are based on the idea of the development of emotional competence, according to Denham (1998). Being a multidimensional and complex concept, emotional competence involves various components, of which the author highlights emotional expression, comprehension and regulation. According to Denham (1998), these components function in an integrated way.

The skills involved in emotional competence are constituted according to the age, in a way that is appropriate to the cultural environment and to the social situation in question, involving recognition of psychological processes within oneself and within others. Thus, emotional competence is revealed in many everyday situations experienced by individuals at all stages of the life cycle and develops from birth throughout life. However, for Denham (2007) it is in childhood that the development of emotional competence gains important space and requires more attention, especially among those aged three/four and five years. Empirical studies have shown that these skills play a central role in children's developmental trajectories, not only for mental health but also for academic success and social competence, supporting cognitive development, readiness, and school adjustment (Curby, Brown, Bassett, \& Denham, 2015; Denham, Bassett, Zinsser, \& Wyatt, 2014; Izard et al., 2001).

Thinking about and investigating the moment of ontogenesis between two and five years, when the child shows marked progress in development in several areas (speech, thought, 
motor, social play), Denham (1998) pondered that children are emotionally more sophisticated than one might think. He argued that the various transformations in emotional competence in this period have led developmental psychologists to try to describe them more fully.

Denham (1998) discussed each of the three core competences related to emotions and considered that emotional expression in young children includes: using gestures to express nonverbal emotional messages about a social situation or relationship; demonstrating empathic involvement with the emotions of other people; displaying complex self-consciousness and social emotions, such as guilt, pride and shame, in appropriate contexts; and realizing that one can feel a certain way "inside", but display different behavior.

For the comprehension of emotions in young children the skills to: discern their emotional states; discern the emotional states of others; and use the vocabulary of emotions were highlighted by Denham (1998). With regard to emotional regulation, the capacities mentioned were: to deal with aversive or distressing emotions, or the situations that arouse them; to deal with pleasurable emotions or the situations that arouse them; and to strategically regulate the emotional experience and expression at appropriate times.

Despite the relevance of the emotions and parenting for studies aimed at children's development, in a review of the literature no national or international instruments were identified that focused on parental beliefs regarding emotions, evaluating the importance attributed by mothers and fathers to the central skills of emotional competence, for the development of the child. Considering the need to evaluate these beliefs for a broader comprehension of the socialization of the emotions of children from four to five years of age, under this focus and from the Brazilian culture, the scale Parental beliefs regarding emotional competence in children (COMPE) was developed.

The aim of this study was to present, briefly, the construction steps of the COMPE scale and to verify the preliminary psychometric param- eters, such as the dimensionality and reliability of the items. It is assumed that the construction and validation of a psychological instrument is of extreme importance for the advancement of the scientific knowledge of a given area.

Measuring instruments, such as scales, require well-defined steps and rigorous techniques in their development (Pasquali, 2010a, 2011), since they aim to quantify unobservable phenomena or latent variables, characteristic of psychological constructs. Pasquali (2010a) highlighted three main poles or procedures called: the theoretical pole, empirical pole and analytical pole. They include specific steps and methods that must be developed in sequence.

Considering that the constitutive definition is the identification of the dimensions and attributes of the constructs, in the present study the constitutive definition stage was carried out according to the theoretical concepts formulated by Denham $(1998,2007)$. Thus, the goal of constructing the scale of parental beliefs about the importance of children's emotional competence was based on theoretical formulations, according to which three main pillars can be focused: the emotional expression (potentially observable changes in the face, voice, body, and activity level due to an internal or external event that provokes an emotion), the comprehension of emotions (ability to identify emotions in oneself and other people and to be able to name them appropriately) and emotional regulation (the ability to deal with emotions, whether pleasurable or distressing, and the situations that promote them).

In this study, for the operational definition, a variety of operational concepts representing emotional expression (using gestures, such as a hug, to express non-verbal emotional messages about a social situation or relationship, expressing facial expressions of emotions, such as a smile), emotional comprehension (realizing that one feels more sadness than anger when the teacher calls for attention; knowing that the father's smile upon arriving home from work should indicate that he is pleased), and emotional regulation (appealing to the mother when the brother takes one's toy, instead of hitting him) were extracted from the literature. 
From these operational concepts, a list of categories was produced that are expressed in unitary and specific tasks, called items. According to Pasquali (2010b), the construction of the items corresponds to the stage of operationalization of the construct and the main source used for the development of this stage is the bibliographical review related to the construct. ${ }^{1}$

The items of the Parental Beliefs regarding Emotional Competence in Children Scale were constructed considering a number of phrases expressing emotional expression, emotional comprehension and emotional regulation, gathered based on the bibliographical review and the experience of the first author. A Likert-type scale was chosen as the structure of the instrument, in which the categories were defined in six grades associated with the importance the participant assigns to the statement: not important, minimally important, slightly important, reasonably important, very important and extremely important. A total of 104 items were constructed according to the constitutive and operational definitions of the formulations of Denham $(1998,2007)$ following the criteria that, according to Pasquali (1998), are: behavioral, objectivity or desirability, simplicity, clarity, relevance, accuracy, variety, modality, typicality and credibility.

Of the 104 items constructed for the Parental Beliefs regarding Emotional Competence in Children Scale, 45 items were from the Emotional expression component, 40 items from the Emotional comprehension component, and 19 items from the Emotional regulation component, all of which were constructed in the form of sentences to be qualified by the respondents. The items were constructed as behavioral representatives of the theoretical formulation of Denham (1998). However, it was necessary to evaluate them through the opinion of experts in the field, known as judges, guaranteeing their validity (Pasquali, 1998, 2010b). Thus, for the semantic analysis of the items and content analysis, the Parental Beliefs regarding Emotional

The pool of items was constructed from the groupings of phenomena raised in the prevalent themes.
Competence in Children Scale was submitted to analysis by judges.

The judges were asked to provide their level of agreement with the items and their opinion on the semantic adequacy, ease of comprehension and relevance of the behavioral representation of each item of the scale and to describe their considerations regarding the construction of the item.

The result of the analysis of the judges culminated in 73 of the initial 104 items being maintained, due to low values obtained in the content validity coefficient (CVC) - lower than 0.80 . Of the items in the theoretical facet of emotional regulation, five were revised by the experts. After the revisions, the scale presented a CVC of 0.99 for both relevance and clarity of the writing of the items, indicating the agreement of the judges regarding the good quality of the content of the scale. This version, composed of 40 items related to emotional expression, 23 related to emotional comprehension and 10 related to emotional regulation, was used for the study presented here, according to the method described below.

\section{Method}

\section{Sample}

The study included 81 parents with children of the required age, of whom $87.7 \%(n=71)$ were female and $12.3 \%(n=10)$ male, with a mean age of 35.21 years $(S D=6.48$, minimum age of 24 and maximum of 54 years), the majority from the state of Rio de Janeiro $(48.1 \%, n=39)$ and half of the sample composed of participants from a total of nine states. Regarding schooling, $40 \%$ $(n=32)$ had a complete or ongoing postgraduate degree, $16 \%(n=13)$ complete higher education, $23 \%(n=19)$ incomplete higher education and $21 \%$ educational levels of less than or equal to complete high school education. Considering the marital status, $85 \%(n=69)$ of the participants reported being in a stable union, $5 \%(n=4)$ reported being separated/divorced and $10 \%(n=8)$ single. The children of the participants had ages ranging from four to five years of age - according to the age range for the use of the scale - 
with a mean age of $M=4.63(S D=0.48)$, being children in the Early Childhood Education level. To be (1) Brazilian, (2) resident in the country, and (3) the father or mother of (4) a child aged from four to five years were the inclusion criteria used, with those that did not fulfill all 4 criteria excluded. Data collection was performed from June to August 2016.

\section{Instruments}

Socio-demographic questionnaire - the participants reported their sex, age, highest level of schooling reached, marital status, family income, profession, professional contract, location, date of birth of the child in the study and characteristics of the people living in the household. Part of the data will be used in subsequent studies.

Emotional Skills Scale - In order to measure the parents' beliefs about different aspects of emotional competence, three theoretical facets were selected, with a total of 73 items for the phase of analysis of the items for evidence of validity. The facet structure represented the theory regarding the organization of emotional competences. However, for measurement purposes, the scale scores an overall dimension of positive parental beliefs regarding the importance of the competencies listed. Low scores or location in lower logits represent participants with low focus or appreciation of emotional competencies in children in the same age range as their children, while the opposite occurs for higher scores or locations. The theoretical facets consist of: (1) emotional expression (40 items), (2) emotional comprehension (23 items) and (3) emotional regulation (10 items).

The scale is introduced with the following text: "Check one of the numbers to say how much you think it is important for the child's development that he/she ...". Responses could be noted on a six-point Likert-type scale, with descriptors ranging from (1) "not important", (2) "minimally important", (3) "slightly important", (4) "reasonably important", (5) "very important" and (6) "extremely important". In clinical or research contexts, calculating the mean of the responses to the instrument is recommended. Future stud- ies will be conducted with the aim of producing interpretation standards, as well as localization percentiles with appropriate reference samples.

\section{Procedure}

The participants responded to online forms made available through Google Docs. The announcement was made on social networks (Facebook, Linkedin and Google+), as well as by e-mail, with a brief presentation text and the link to the study form. Before responding to the instruments, however, they first had to read and agree to the terms of consent. After reading and agreeing to participate in the study, the form was followed by the sociodemographic questionnaire and, finally, the COMPE scale was presented. When completing the form, an option to send the completed form was available, followed by a statement thanking them for participating. In a pilot study, it was found that filling in the entire form took from 20 to 30 minutes.

\section{Data Analysis}

The software used for the analyses was $\mathrm{R}$ v3.3.1 ( $R$ Core Team, 2016). The dimensionality analysis was conducted using the nFactors package (Raiche \& Magis, 2010). The reliability and item analysis was conducted using the mirt package (Chalmers, 2012).

The dimensionality in the $n$ Factors package can be analyzed through a plurality of rules, considering that it returns the quantity of factors through the Kaiser criterion, of eigenvalues greater than 1.00. It also presents the number of factors retained in the parallel analysis, using the optimized coordinate method and, finally, the acceleration factor. Raiche and Magis (2010) recommend that it is decided by the number of factors retained throughout all the procedures.

The reliability analysis was conducted both through Cronbach's alpha coefficient, usually reported in the psychometric literature, as well as the empirical reliability coefficient (ERC). The ERC is obtained considering a secondary estimate of the latent trait and its standard errors returned by the fscores command (Chalmers, 2012). 
The analysis of the items was conducted using the Item Response Theory paradigm, according to the Generalized Partial Credit Model (GPCM). Considering that the present study obtained a smaller than necessary sample due to the collection challenges, the Metropolis-Hastings Robbins-Monro (MHRM) resampling method was used in order to increase the robustness of the estimates and subsequent analyses (Chalmers, 2012). Three criteria were used in order to select items: (1) chi-square goodness of fit test for each item, where non-significant values indicate a fit of the characteristic curve of the item to the observed response patterns; and (2) level of discrimination between 0.70 and 1.50 while observing the quality of the item and test information (Baker, 2001; De Ayala, 2009). Among the characteristics of the items reported in the GPCM model, the level of discrimination and the level of the mean trait presented by the degrees of response of each item are included.

\section{Results}

\section{Dimensionality}

The initial investigation of the dimensionality of the scale indicated a total of 15 dimensions with eigenvalues above 1.00 , with five dimensions indicated in the parallel analysis. Analysis of the optimized coordinates maintained five dimensions, however, four dimensions were lost in the acceleration factor analysis, leaving only a single dimension that accumulated $37 \%$.

After the item removal process, which will be reported in the item fit section, there was a loss of the number of dimensions, with the scale having seven dimensions detected within the eigenvalue criterion: three dimensions for the parallel analysis, three dimensions for the optimized coordinates and one dimension, at the end, for the acceleration factor, with the retention of $29 \%$ of the explained variance.

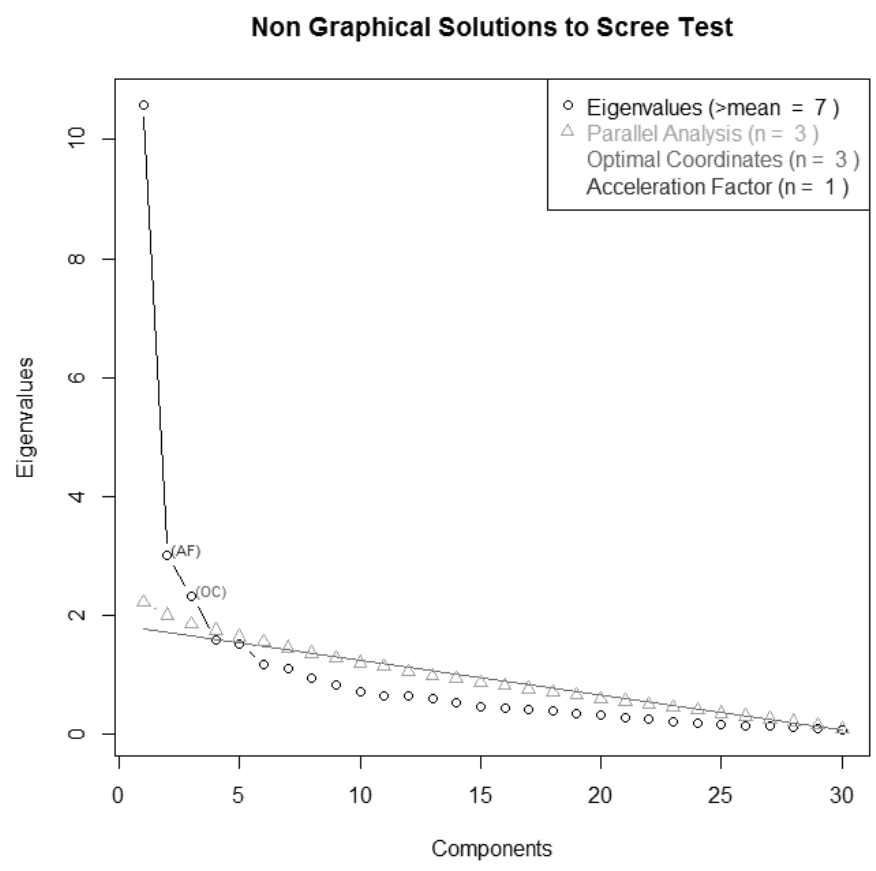

Figure 1. Non-graphical Solutions of the Emotional Competence Scale. Reliability.

Although the present article includes an analysis in IRT, it was chosen to report the Cronbach's alpha coefficient due to its frequent use in the literature. The alpha coefficient obtained prior to the item removal was 0.97 , with only
Q1, Q3 and Q70 presenting item-total correlation of less than 0.30 . The empirical reliability coefficient computed by the mirt package also presented a value of 0.97 . 
After the item removal, in the IRT fit process, the alpha coefficient was reduced to 0.93 and none of the items presented item-total correlation lower than 0.30 . In turn, the empirical reliability coefficient presented a value of 0.94 . Figure 2 shows that the instrument retained high reliability values for the largest portion of the latent trait continuum.

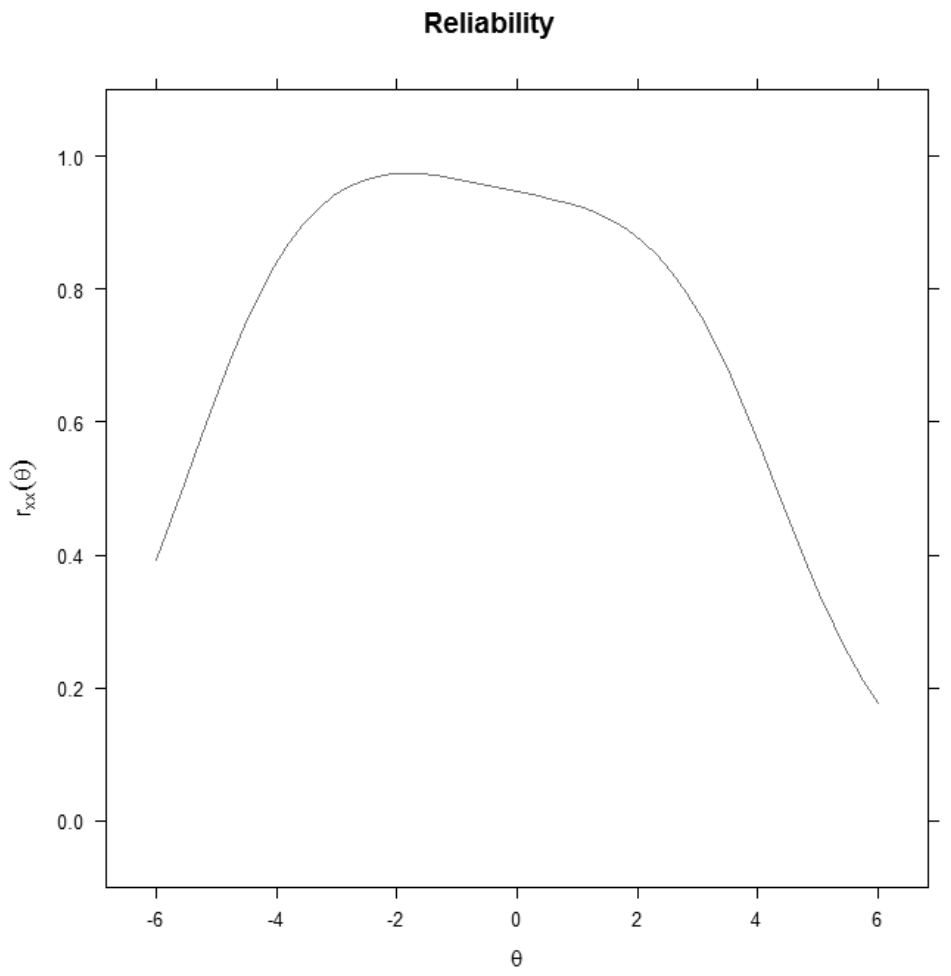

Figure 2. Reliability graph for the ECS presenting the skill levels interval between -6 and +6 .

\section{Fit of the Items and Localization}

The first parameter for the item selection was the chi-square test, with the aim of eliminating items that had a poor approximation between the characteristic curve of the item and the observed response patterns. In this sense, the problematic items were the items Q11 $\left(X^{2}=19.66\right.$, $p=.033), \quad \mathrm{Q} 12 \quad\left(X^{2}=20.22, \quad p=.042\right), \quad \mathrm{Q} 17$ $\left(X^{2}=21.00, p=.021\right), \mathrm{Q} 29\left(X^{2}=25.73, p=.012\right)$, Q39 $\left(X^{2}=20.94, \quad p=.022\right), \quad$ Q50 $\quad\left(X^{2}=19.65\right.$, $p=.033), \mathrm{Q} 55 \quad\left(X^{2}=25.67, p=.042\right)$ and Q64 $\left(X^{2}=23.89, p=.012\right)$.

The second step was the exclusion of items that had discrimination levels below 0.70 or higher than 1.50. The items removed due to low levels of discrimination were as follows: Q1 $(a=0.68)$, Q3 $(a=0.41)$, Q6 $(a=0.31)$, Q25 $(a=0.57), \mathrm{Q} 40 \quad(a=0.61), \mathrm{Q} 55(a=0.38), \mathrm{Q} 61$ $(a=0.36), \mathrm{Q} 70(a=0.25)$ and Q71 $(a=0.57)$. It should be highlighted that all the items mentioned with low discrimination presented item information functions practically represented by straight or low relief lines. The number of items, on the other hand, removed due to an excess of discrimination was high, including items Q2 $(a=1.56), \mathrm{Q} 11(a=2.03), \mathrm{Q} 20(a=1.55), \mathrm{Q} 24$ $(a=1.84), \mathrm{Q} 26(a=1.93), \mathrm{Q} 27(a=3.19), \mathrm{Q} 28$ $(a=1.96), \mathrm{Q} 30 \quad(a=3.25), \mathrm{Q} 35(a=2.05), \mathrm{Q} 36$ $(a=2.73), \mathrm{Q} 37 \quad(a=3.07), \mathrm{Q} 38(a=3.37), \mathrm{Q} 41$ $(a=2.22), \mathrm{Q} 43(a=2.42), \mathrm{Q} 44(a=1.95), \mathrm{Q} 47$ $(a=2.38), \mathrm{Q} 48(a=1.67), \mathrm{Q} 50(a=1.50), \mathrm{Q} 51$ $(a=2.27), \mathrm{Q} 53(a=1.88), \mathrm{Q} 54(a=1.75), \mathrm{Q} 57$ $(a=1.67), \mathrm{Q} 59(a=1.83), \mathrm{Q} 63(a=2.28), \mathrm{Q} 64$ $(a=1.56), \mathrm{Q} 65(a=1.65), \mathrm{Q} 66(a=2.15), \mathrm{Q} 68$ $(a=1.63)$, Q69 $(a=1.79)$ and Q73 ( $a=1.97)$. The parameters and fit of the remaining items are presented in table 1 . 
Table 1

Discrimination Parameters (a), Localization (b) and Fit of the Items through the Chi-Square Test including the Test Statistic $\left(\mathrm{X}^{2}\right)$, Degrees of Freedom $(d f)$ and Level of Statistical Significance ( $p$-sig)

\begin{tabular}{|c|c|c|c|c|c|}
\hline List of items & $a$ & $b$ & $X^{2}$ & $d f$ & $p$-sig \\
\hline Emotional Expression & - & - & - & - & - \\
\hline Q4 & 1.06 & -1.70 & 16.95 & 12 & .152 \\
\hline Q8 & 1.07 & -1.08 & 20.13 & 13 & .092 \\
\hline Q10 & 1.14 & -1.69 & 10.60 & 11 & .478 \\
\hline Q15 & 1.29 & -0.47 & 12.14 & 11 & .353 \\
\hline Q18 & 1.29 & -0.44 & 17.64 & 14 & .224 \\
\hline Q19 & 1.30 & -1.07 & 7.75 & 10 & .654 \\
\hline Q21 & 1.42 & -0.88 & 17.96 & 13 & .159 \\
\hline Q33 & 1.05 & -1.26 & 12.18 & 10 & .273 \\
\hline Q34 & 1.23 & -0.89 & 13.59 & 11 & .257 \\
\hline Q42 & 1.44 & -0.75 & 9.58 & 11 & .568 \\
\hline Q46 & 1.19 & -0.76 & 17.10 & 12 & .146 \\
\hline Q56 & 0.94 & -0.99 & 18.78 & 12 & .094 \\
\hline Q60 & 1.30 & -0.86 & 15.01 & 11 & .182 \\
\hline Q62 & 1.32 & -0.97 & 14.48 & 11 & .208 \\
\hline Q72 & 1.13 & -0.70 & 10.37 & 12 & .584 \\
\hline Emotional Understanding & - & - & - & - & - \\
\hline Q5 & 1.10 & -1.13 & 11.24 & 15 & .736 \\
\hline Q7 & 1.14 & -0.61 & 16.74 & 12 & .160 \\
\hline Q9 & 1.19 & -0.87 & 11.63 & 11 & .392 \\
\hline Q13 & 0.82 & -0.69 & 13.63 & 12 & .325 \\
\hline Q16 & 0.75 & -0.89 & 10.68 & 12 & .556 \\
\hline Q23 & 1.43 & -0.81 & 14.36 & 12 & .278 \\
\hline Q31 & 1.22 & -1.25 & 6.04 & 10 & .812 \\
\hline Q45 & 1.32 & -0.67 & 13.09 & 12 & .362 \\
\hline Q52 & 1.19 & -0.63 & 10.11 & 12 & .606 \\
\hline Q58 & 1.47 & -0.67 & 11.17 & 10 & .344 \\
\hline Emotional Regulation & - & - & - & - & - \\
\hline Q14 & 0.75 & -1.30 & 17.05 & 14 & .253 \\
\hline Q22 & 1.09 & -1.67 & 13.77 & 12 & .316 \\
\hline Q32 & 1.16 & -1.43 & 7.41 & 12 & .830 \\
\hline Q49 & 1.22 & -1.40 & 8.68 & 11 & .652 \\
\hline Q67 & 0.85 & -0.84 & 16.32 & 13 & .232 \\
\hline
\end{tabular}

The items that presented the lowest level of localization or were less revealing were: Q4 $(b=-1.70), \mathrm{Q} 10(b=-1.69), \mathrm{Q} 22(b=-1.67), \mathrm{Q} 32$ $(b=-1.43)$ and Q49 $(b=-1.40)$. In turn, the most revealing items or those that required the highest trait level were: Q18 $(b=-0.44), \mathrm{Q} 15(b=-0.47)$, Q7 $(b=-0.61)$, Q52 $(b=-0.63)$ and Q58 $(b=-0.67)$. The items that presented the highest levels of discrimination were: Q45 ( $a=1.32), \mathrm{Q} 21(a=1.42)$, $\mathrm{Q} 23(a=1.43), \mathrm{Q} 42(a=1.44)$ and Q58 $(a=1.47)$. 
For the remaining items, the Test Information Function, presented in Figure 3, indicates that the measurement error increased rapidly, especially before the region near to the trait levels located at $b=-4.00$ and near to +2.00 . The information peak also precedes the localization of $b=0.00$. The information is essential to understand what the best use of the scale would be. In this sense, instruments with higher information level at low trait levels are more useful as screening instruments.

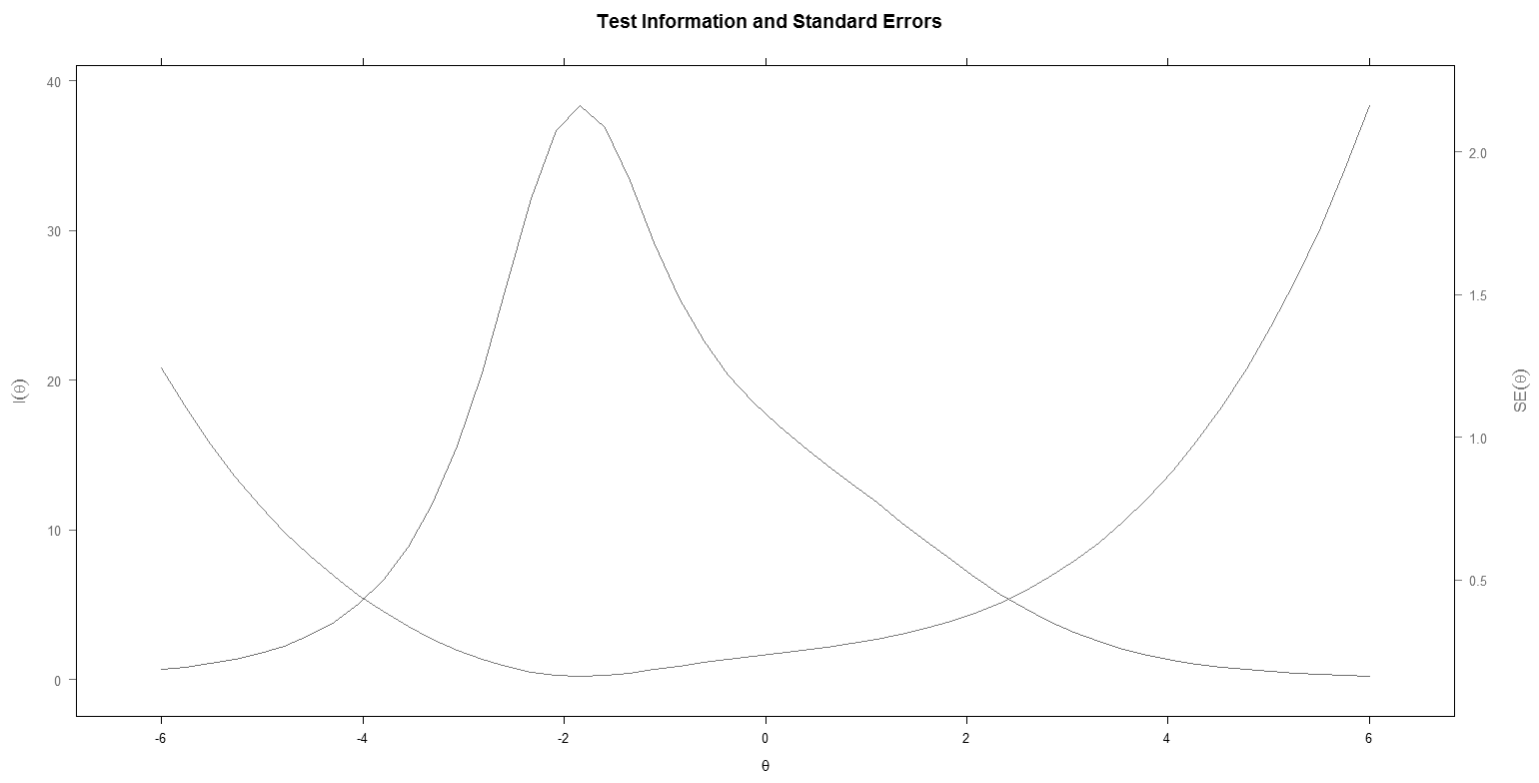

Figure 3. Test information function. The blue curve indicates the information curve, while the pink curve indicates the error distribution.

\section{Discussion and Final Considerations}

The COMPE was constructed following three phases, namely: (1) elaboration of items from the theoretical framework, with 104 items being established; (2) evaluation of these items by judges, with only those that achieved a satisfactory content validity coefficient being retained, leading to a new total of 73 items, (3) submission of the 73 item version to item analysis procedures through Item Response Theory, with 30 items being retained in total, ending a rigorous process for a first version with potential for use.

The results of the analyses are indicative of obtaining a first version of COMPE with potential for use. This constitutes a methodological contribution to research in the field of studies in which it is included, as Brazilian instruments that offer a reliable and valid measure of parental beliefs regarding emotional competences in children have not been identified. It is understood that what parents think and believe about how the child develops emotionally and which main skills should be developed in this area are high impact components critical for full and healthy development (Denham, 2007; Parker et al., 2012; Trommsdorff \& Cole, 2011). It can be stated that in the present study an initial step was taken in the constitution of an instrument that reflects this theoretical concept, so that the COMPE in its form achieved offers satisfactory reliability and validity indices.

Through the results it was possible to arrive at a set of items the model curve of which fits the observed responses. However, the representation of the behaviors and the discrimination capacity follow as a challenge for the next versions. The first question concerns the distribution of difficulty levels, which presented a predominantly negative localization characteristic. This means 
that most of the traits listed require a relatively low attitude in relation to the target attitude. One of the future goals for new versions will be to include items that represent less available or more difficult attitudes. Likewise, such items would make greater sensitivity possible at higher trait levels than those shown in, for example, Figure 3 of this article.

Regarding the difficulty levels, one of the points of attention was that items Q18, Q15, Q7, Q52 and Q58 reached the highest levels of difficulty. This is possibly related to the fact that almost all, with the exception of Q58, are associated with emotions considered negative (such as guilt, shame, and anger). This result may therefore be associated with a cultural trait of parental beliefs (Denham, 2007; Trommsdorff \& Cole, 2011), with Brazilian parents not valorizing or expecting children in the age range contemplated to have skills linked to their expression or comprehension.

It is possible to state that one of the advantages of the present study is the elaboration of a measure for parental beliefs about emotional competences that considers the developmental context of the child, i.e., that of Brazilian mothers and fathers. The second advantage of the present study is the use of the Item Response Theory as an analysis procedure. Among the advantages listed by Hambleton, Swaminathan, and Rogers (1991) it is possible to highlight: (a) a more adequate characterization of the relationship between measurement and measurement error; (b) better characterization of information related to the scalability of items and people, as well as information that richly contributes to the selection of items and, finally; (c) estimates that are not normally sample or test-dependent.

Among the weaknesses of the study the limited sample can be highlighted. The aim of restricting the age range in which the children of the parents interviewed could be included was to propose an instrument appropriate for a real context and that adhered to that indicated by the author of the theoretical model in her practical experience with children at the age when the development of these competencies becomes more prominent (Denham, 2007). It was understood that the notions and cognitions of fathers and mothers about the emotional competences of children is something that is both situated in a specific sociocultural context and changes in the stages of the child's life cycle.

Another reason that may be hypothesized for the restriction of the sample size is the difficulty in obtaining participants who were willing to give up about 20 to 30 minutes of their time to complete the online form. The intended participants were, to a large extent, people who were in a moment of life in which they are presumed to be engaged in a professional activity (to be working) and parents of a child, with all the responsibility and tasks involved. It was attempted to circumvent the sample size using resampling techniques to provide greater robustness to the estimation and to the fit tests.

Furthermore, in terms of study limitations, the parents' level of knowledge about their own emotional competencies was not explored, which could affect the results obtained and allow a better interpretation of them. The convenience of this verification should be assessed for future investigations. However, there is no doubt that the analyses presented here need to increase the statistical power in the future.

In addition to the statistical power, another future expectation is to also carry out tests on the stability of the beliefs about emotional competences relative to the ages studied, in order to understand how they can change over time. Based on the concept that parental beliefs are constituted according to specific cultural models and meanings shared by the members of the sociocultural context in which they live, these beliefs are understood to undergo changes over the course of time.

Considering the limitations and contributions of the study, it is understood that its purpose was to present the construction steps of the COMPE scale and to verify the preliminary psychometric parameters, such as dimensionality and reliability of the items. The results obtained with the application performed are consistent with the model used. The scale is considered to present properties that allow its use in research involving parental beliefs and 
emotions, with reliability. In addition, it is an instrument specially constructed for use with the Brazilian population, which represents an advance considering the lack of instruments with this focus and aim in the country.

\section{References}

Baker, F. (2001). The Basics of Item Response Theory. Washington: ERIC Clearinghouse on Assessment and Evaluation.

Bohanek, J., Fivush, R., Zaman, W., Lepore, C., Merchant, S., \& Duke, M. (2009). Narrative interaction in family dinnertime conversations. MerrillPalmer Quarterly, 55(4), 488-515. doi: 10.1353/ mpq.0.0031

Boyatzis, R. E., \& Sala, F. (2004). Assessing emotional intelligence competencies. In G. Geher (Ed.), The measurement of emotional intelligence (pp. 147-80). New York: Novas Science.

Chalmers, R. P. (2012). mirt: A multidimensional item response theory package for the $\mathrm{R}$ environment. Journal of Statistical Software, 48(6), 1-29. doi: http://hdl.handle.net/10.18637/jss. v048.i06

Curby, T. W., Brown, C. A., Bassett, H. H., \& Denham, S. A. (2015). Associations between preschoolers' social-emotional competence and preliteracy skills. Infant and Child Development, 24, 549-570. doi: https://doi.org/10.1002/ icd.1899

Damásio, A. R. (2009). Em busca de Espinosa: Prazer e dor na ciência dos sentimentos. São Paulo, SP: Companhia das Letras.

De Ayala, R. J. (2009). The Theory and practice of item Response Theory. New York: The Guilford Press.

Denham, S. A. (1998). Emotional development in young children. New York: The Guilford Press.

Denham, S. A. (2007). Dealing with feelings: How children negotiate the worlds of emotions and social relationships. Cognition, Brain \& Behavior, 11, 1-48.

Denham, S. A., Bassett, H. H., Zinsser, K., \& Wyatt, T. M. (2014). How preschoolers' social-emotional learning predicts their early school success: Developing theory-promoting, competency-based assessments. Infant and Child Development, 23, 426-454. doi: https://doi.org/10.1002/icd.1840
Denham, S. A., Ferrier, D. E., Howarth, G. Z., Herndon, K. J., \& Bassett, H. H. (2016). Key considerations in assessing young children's emotional competence. Cambridge Journal of Education, 46(3), 299-317. doi: https://doi.org/10.1080/030 5764X.2016.1146659

Finlon, K. J., Izard, C. E., Seidenfeld, A., Johnson, S. R., Cavadel, E. W., Ewing, E. S. K., \& Morgan, J. K. (2015). Emotion-based preventive intervention: Effectively promoting emotion knowledge and adaptive behavior among at-risk preschoolers. Development and Psychopathology, 27, 1353-1365. doi: 10.1017/S0954579414001461

Fivush, R. (2008). Remembering and reminiscing: How individual lives are constructed in family narratives. Memory Studies, 1, 49-58. doi: https://doi.org/10.1177/1750698007083888

Goleman, D. (1995). Inteligência Emocional - A teoria revolucionária que redefine o que é ser inteligente. Rio de Janeiro, RJ: Objetiva.

Gottman, J. M., Katz, L. F., \& Hooven, C. (1996). Parental Meta-Emotion Philosophy and the emotional life of families: Theoretical models and preliminary data. Journal of Family Psychology, 10(3), 243-268

Halberstadt, A. G., Dunsmore, J. C., Bryant, A., Jr., Parker, A. E., Beale, K. R., \& Thompson, J. A. (2013). Development of the Parents' Beliefs about Children's Emotions Questionnaire. Psychological Assessment, 25, 1195-1210. doi: 10.1037/a0033695

Hambleton, R. K., Swaminathan, H., \& Rogers, H. J. (1991). Fundamentals of item response theory. London: Sage.

Harkness, S., \& Super, C. (2010). Parental ethnotheories in children learning. In D. F. Lancy, J. Bock, \& S. Gaskins (Eds.), The Anthropology of Learning in childhood (pp. 65-84). Plymouth, UK: AltaMira Press.

Izard, C., Fine, S., Schultz, D., Mostow, A., Ackerman, B., \& Youngstrom, E. (2001). Emotional knowledge as a predictor of social behavior and academic competence in children at risk. Psychological Science, 12, 18-23. doi: https://doi. org/10.1111/1467-9280.00304

Lozada, F. T., Halberstadt, A. G., Craig, A. B., Dennis, P. A., \& Dunsmore, J. C. (2016). Parents' beliefs about children's emotions and parents' emotion-related conversations with their children. Journal of Child and Family Studies, 25, 
$1525-1538$.

Mendonça, S. S. (2009). Competências profissionais dos enfermeiros: A excelência do cuidar. Penafiel, Portugal: Penagráfica-Artes.

Parker, A. E, Halberstadt, A. G., Dunsmore, J. C., Townley, G., Bryant, A., Thompson, J. A., \& Beale, K. S. (2012). Emotions are a window into one's heart": A qualitative analysis of parental beliefs about children's emotions across three ethnic groups. Monographs of the Society for Research in Child Development, 77(3), 1-136. doi: 10.1111/j.1540-5834.2012.00676.x

Pasquali, L. (1998). Psicometria: Teoria e aplicações. Brasília, DF: Editora da Universidade de Brasília.

Pasquali, L. (2010a). Instrumentação Psicológica: Fundamentos e Práticas. Porto Alegre, RS: Artmed.

Pasquali, L. (2010b). Testes referentes a construto: Teoria e modelo de construção. In L. Pasquali (Ed.), Instrumentação psicológica: Fundamentos e práticas (pp. 165-198). Porto Alegre, RS: Artmed.

Pasquali, L. (2011). Psicometria: Teoria dos testes na psicologia e na educação. Petrópolis, RJ: Vozes.
Raiche, G., \& Magis, D. (2010). nFactors: An R package for parallel analysis and non graphical solutions to the Cattell scree test (R package version 2.3). Montreal.

Saarni, C. (1999). How we become emotionally competent. In C. Saarni (Ed.), The Development of Emotional Competence (pp. 54-78). New York: The Guilford Press.

Sheffield-Morris, A., Silk, J., Steinberg, L., Myers, S., \& Robinson, L. (2007). The role of the family context in the development of emotion regulation. Social Development, 16, 361-388. doi: 10.1111/j.1467-9507.2007.00389.x

Trommsdorff, G., \& Cole, P. M. (2011). Emotion self-regulation, and social behavior in cultural contexts. In X. Chen \& K. H. Rubin (Eds.), Socioemotional development in cultural context (pp. 131-163). New York: The Guilford Press.

Recebido: 29/12//2016

$1^{a}$ revisão: $14 / 08 / 2017$

Aceite final: 06/11/2017 


\section{Annexes}

\section{COMPE - List of items in the Electronic Form}

\section{O quanto você concorda que "É importante para o desenvolvimento da criança que ela..."}

\begin{tabular}{|c|c|c|}
\hline Original* & Final** & Itens \\
\hline Q4 & Q1 & Expresse a emoção que sente quando está contente brincando com outras crianças. \\
\hline Q5 & Q2 & Entenda que o que outra pessoa (adulto ou criança) está sentindo se chama medo. \\
\hline Q7 & Q3 & $\begin{array}{l}\text { Saiba que se alguém está se mostrando com raiva é porque ocorreu algo que lhe irritou ou abor- } \\
\text { receu muito. }\end{array}$ \\
\hline Q8 & Q4 & Expresse a emoção que sente quando outra criança faz alguma coisa que estraga a brincadeira. \\
\hline Q9 & Q5 & Compreenda que o que outra pessoa (adulto ou criança) está sentindo é tristeza. \\
\hline Q10 & Q6 & Demonstre alegria quando está feliz. \\
\hline Q13 & Q7 & Saiba que o que outra pessoa (adulto ou criança) está sentindo se chama orgulho. \\
\hline Q14 & Q8 & $\begin{array}{l}\text { Peça ajuda à mãe ou outra pessoa em quem confie, quando está com muita raiva porque uma } \\
\text { criança tomou o seu brinquedo e quebrou. }\end{array}$ \\
\hline Q15 & Q9 & Mostre que ficou com raiva quando alguma coisa que queria não deu certo. \\
\hline Q16 & Q10 & $\begin{array}{l}\text { Compreenda que se alguém parece envergonhado é porque está sem jeito diante de outras pes- } \\
\text { soas ou de certas situações. }\end{array}$ \\
\hline Q18 & Q11 & Expresse vergonha quando se sente constrangida diante de alguém ou por alguma situação. \\
\hline Q19 & Q12 & Expresse a emoção que sente quando vê um cão latindo se aproximando de forma ameaçadora. \\
\hline Q21 & Q13 & Manifeste orgulho quando fez algo que sabe que seus pais consideram muito importante. \\
\hline Q22 & Q14 & $\begin{array}{l}\text { Encontre uma maneira eficiente de buscar ajuda quando precisa suportar o medo que está sen- } \\
\text { tindo. }\end{array}$ \\
\hline Q23 & Q15 & Compreenda que o que outra pessoa (adulto ou criança) está sentindo se chama raiva. \\
\hline Q31 & Q16 & Entenda que o que está sentindo naquela situação é tristeza e não raiva. \\
\hline Q32 & Q17 & $\begin{array}{l}\text { Peça ajuda à mãe ou outra pessoa em quem confie, para conseguir aguentar o medo e não entrar } \\
\text { em pânico. }\end{array}$ \\
\hline Q33 & Q18 & Demonstre que está orgulhosa por ter conseguido fazer aquilo que tanto queria. \\
\hline Q34 & Q19 & Expresse que está brava quando alguma coisa que não lhe agrada acontece. \\
\hline Q42 & Q20 & Expresse a emoção que sente quando seu brinquedo favorito cai no chão e quebra todo. \\
\hline Q45 & Q21 & Compreenda que o que outra pessoa (adulto ou criança) está sentindo é vergonha. \\
\hline Q46 & Q22 & Mostre que ficou com raiva quando aconteceu algo que lhe contrariou. \\
\hline Q49 & Q23 & $\begin{array}{l}\text { Controle a raiva para não agredir outra criança que tomou o seu brinquedo e quebrou, mesmo } \\
\text { que fique muito aborrecida. }\end{array}$ \\
\hline Q52 & Q24 & Tenha conhecimento de que o que outra pessoa (adulto ou criança) está sentindo é culpa. \\
\hline Q56 & Q25 & Demonstre que ficou com raiva quando outra criança lhe bateu com força. \\
\hline Q58 & Q26 & Entenda que se alguém está expressando alegria significa que algo de bom aconteceu. \\
\hline Q60 & Q27 & Demonstre medo quando vê um cão latindo se aproximando de forma ameaçadora. \\
\hline Q62 & Q28 & Demonstre orgulho quando fez algo que agradou muito a seus pais. \\
\hline Q67 & Q29 & Regule a forma como mostra suas emoções para que sejam adequadas à situação e ao ambiente. \\
\hline Q72 & Q30 & Demonstre que está com medo quando ouve algo que a deixa assustada. \\
\hline
\end{tabular}

Obs: *Original number referring to the initial version prior to deletion of items in TRI procedures. **Final numbering refers to item number after deletion 